Збірник наукових пращь Державного науково-дослідного інституту випробувань і сертифікачії озброєння та військової техніки. 2019. Вип. № 2

Солодчук М.О., Телевний І.В., Геращенко М.М. Державний науково-дослідний інститут випробувань і сертифікації озброєння та військової техніки

Сподін О.І., Брайко В.В. Товариство з обмеженою відповідальністю “Науково-виробнича фірма "Адрон”

\title{
ОСОБЛИВОСТІ ВИПРОБУВАНЬ УДАРНИХ БЕЗПІЛОТНИХ АВІАЦІЙНИХ КОМПЛЕКСІВ ТИПУ “КАМІКАДЗЕ" 3 ТЕРМОБАРИЧНОЮ БОЙОВОЮ ЧАСТИНОЮ
}

Враховуючи відсутність типових програм та методик випробувань БпАК типу “камікадзе”, було вирішено сформувати ієрархію показників та критерїв, які надають змогу оиінити дослідний зразок БпАК, як ОВТ з урахуванням досвіду країн НАТО. Запропоновано комплекс рекомендацій, які направлені на підвищення якості організачії та проведення випробувань безпілотних авіаційних комплексів типу "Камікадзе” з термобаричною бойовою частиною.

Ключові слова: ударні безпілотні авіаційні комплекси, програми та методики проведення випробувань БпАК, БпАК з термобаричною бойовою частиною, випробування БпАК

Постановка проблеми. В умовах анексії Автономної республіки Крим Російською федерацією її участі в збройній агресії на сході України, набуло гострої актуальності питання переоснащення Збройних Силу України на сучасні системи озброєння.

При веденні бойових дій в умовах, коли противник здійснює акти збройної агресії прикриваючись мирним населенням, Збройні Сили України потребують оснащення високоточною зброєю, яка дозволить знищувати цілі з високою ймовірністю та одночасно гарантує безпеку мирному населенню. 3 усього різноманіття озброєння та військової техніки (далі - ОВТ), що розробляється підприємствами промисловості України, варто виділити ударні безпілотні авіаційні комплекси (далі - БпАК) типу “камікадзе". Одночасно не сформовано системних підходів щодо випробувань БпАК зазначеного типу і відповідно відсутні програмно-методичні документи для оцінки таких комплексів.

Актуальність дослідження. Передбачаючи актуальність зазначеної тематики, Державним науково-дослідним інститутом випробувань і сертифікації озброєння та військової техніки (далі - ДНДІ ВС ОВТ) ініційовано проведення науково-дослідної роботи (далі - НДР) “Дослідження можливостей застосування безпілотних авіаційних комплексів виробництва ТОВ “КОРТ” в інтересах Збройних Сил України, в ході проведення якої набуло суттєвого значення питання організації та проведення випробувань БпАК цього типу. Основним регламентуючим документом, в ході проведення випробувань, є Програма та методики.

Отже, перед фахівцями ДНДІ ВС ОВТ постало питання щодо розробки Програми та методик проведення випробувань БпАК типу “камікадзе”. Враховуючи відсутність типових програм та методик, було вирішено сформувати ієрархію показників та критеріїв, які надають змогу оцінити дослідний зразок БпАК як ОВТ, з урахуванням досвіду країн НАТО.

Основна частина. Об'єктом випробувань стає БпАК “RAM UAV” виробництва TOB “КОРТ”. Виробник обладнав безпілотний літальний апарат (далі - БпЛА) термобаричною бойовою частиною (далі - ТБЧ) виробництва ТОВ “Науково-виробнича фірма “Адрон”. За фактом на випробування надавався тип БпАК, який ще не стоїть на озброєнні (не експлуатується) у Збройних Силах України.

Концептуальне виконання БпАК інноваційне у вітчизняній промисловості. Особливої специфіки додає те, що в якості бойової частини використовується ТБЧ. 
Для спрощення організації проведення випробувань та для більш глибокого і якісного вивчення дослідного зразка БпАК “RAM UAV”, випробування було розділено на наступні етапи:

$$
\begin{array}{ll}
\text { - } & \text { лабораторний; } \\
\text { - } & \text { наземний; } \\
\text { - } & \text { полігонний; } \\
\text { - } & \text { льотний. }
\end{array}
$$

На лабораторному етапі особливу увагу було приділено оцінці безпечності при експлуатації ТБЧ, а саме:

- $\quad$ оцінці міцності та безпеки ТБЧ;

- $\quad$ оцінці стійкості ТБЧ до дії підвищеної температури середовища;

- $\quad$ оцінці стійкості ТБЧ до дії зниженої температури середовища;

- $\quad$ оцінці стійкості ТБЧ до дії синусоїдальної вібрації;

- $\quad$ оцінці міцності БЧ при імітації транспортування трясінням.

За результатом аналізу отриманих даних зроблено висновок, щодо безпечності застосування на БпАК в якості бойової частини ТБЧ [3].

На наземному етапі випробувань отримані позитивні результати при вивченні стандартних властивостей БпАК (за антологією проведення випробувань не ударних БпАК інших типів).

На полігонних випробуваннях [1-2] перевірялись характеристики ТБЧ та нових термобаричних сумішей (далі - ТБС).

Хід виконання експерименту: ТБС масою 50 г підвищено на спеціальній тринозі на висоту одного метра над рівнем землі. Ліворуч і праворуч від триноги на відстані одного метру від іiї центру були розміщені датчики для реєстрації швидкості поширення вибухової хвилі і тиску. Зразок суміші споряджено електродетонатором та для здійснення підриву 3’єднано з конденсаторною підривною машинкою “КПМ-1”.

\begin{tabular}{|c|c|c|c|c|}
\hline $\begin{array}{l}\text { Назва } \\
\text { суміші }\end{array}$ & Фото & $\mathrm{R}, \mathrm{m}$ & $\mathrm{P}, \mathrm{kPa}$ & $\mathrm{V}, \mathrm{mps}$ \\
\hline \multirow{4}{*}{ “№ 1a" } & & \multirow{4}{*}{0,38} & 40,1 & 394,4 \\
\hline & & & 28,1 & 379,0 \\
\hline & & & & \\
\hline & & & 97,8 & 461,3 \\
\hline \multirow{3}{*}{ “№ 1T" } & & \multirow{3}{*}{0,64} & 38,7 & 392,7 \\
\hline & & & 97,4 & 391,1 \\
\hline & $x=11$ & & - & - \\
\hline
\end{tabular}

У результаті випробувань отримані наступні результати (Таблиця 1).

Таблиця 1

Результати випробувань ТБС 
Закінчення таблиці 1

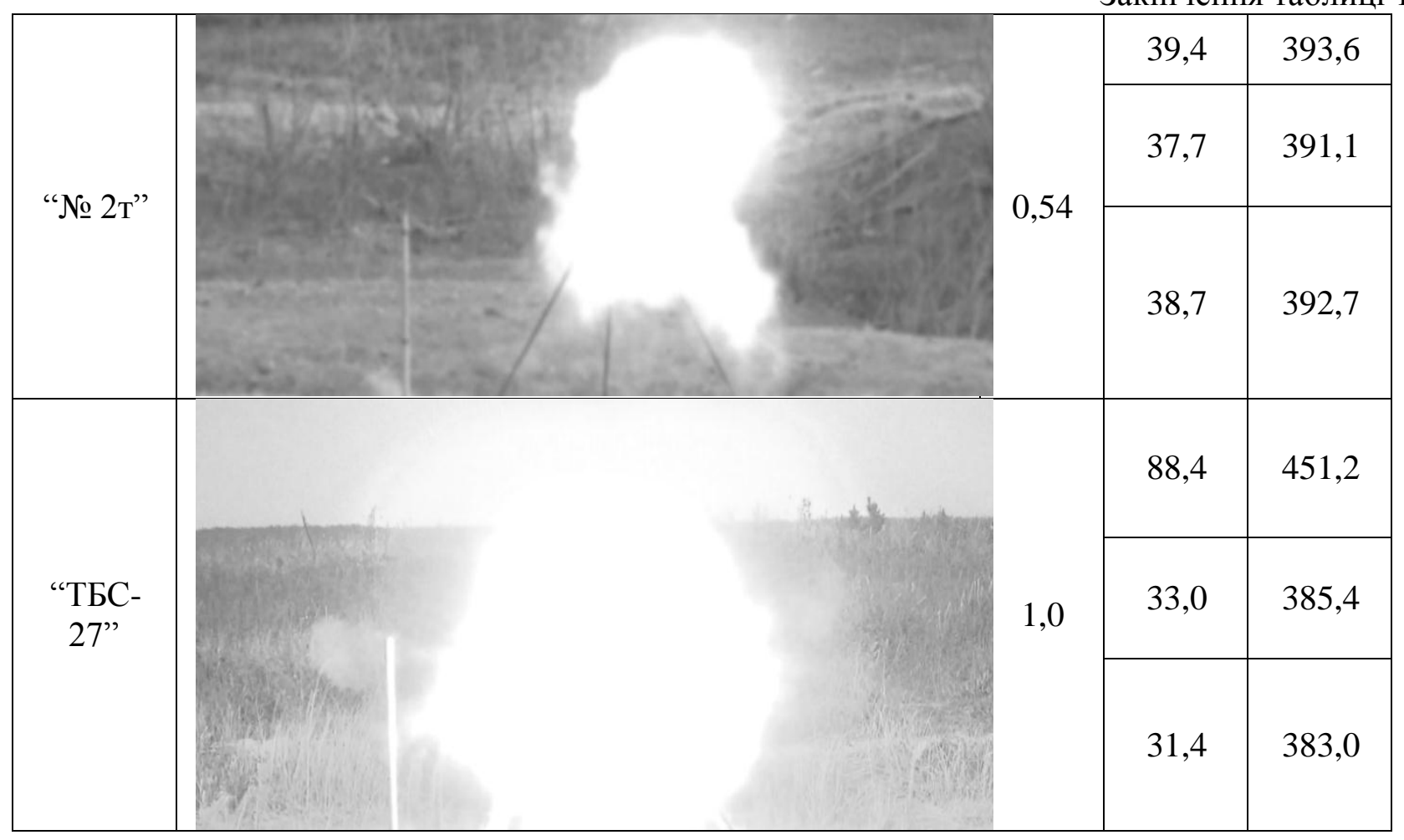

Отже, максимальний радіус вогняної хмари дослідного зразка термобаричної суміші “ТБС-27” становить - 1 м.

На льотному етапі основним показником оцінки БпАК є точність.

Точність влучання визначається в картинній площині БпЛА (площина, яка перпендикулярна вектору швидкості БПЛА в момент прольоту цілі, яка проходить через точку прицілювання). Точність влучання характеризується промахом у картинній площині найкоротшою відстанню між точкою прицілювання та лінією, що співпадає 3 напрямком вектора швидкості БпЛА у момент прольоту цілі.

Координати точки падіння БпЛА на грунт у полігонній системі координат Хз і ,Уз i, $\mathrm{Z}_{3}$ i. Вісь OХз направлена за заданим фіксованим напрямом, вісь ОУз вертикально вверх, вісь $\mathrm{OZ}$ перпендикулярно вісі ОХз, дивлячись зверху на ціль.

Кут пікірування БпЛА при польоті на ціль - кут між вектором швидкості БпЛА та тї проекції на площу ХзOZ3 - $\Theta$ (при пікіруванні від’ємна). Якщо відомий кут між віссю ОХз та проекцією напрямку вектору швидкості БпЛА на площу ХзОУ $-\Theta_{3}^{*}$, тоді:

$$
\theta=\operatorname{arctg}\left(\cos \psi \operatorname{tg} \theta^{*}\right) \text {, }
$$

де $\psi$ - кут атаки БпЛА на ціль.

Координати центру цілі в полігонній системі Хц, Уц, Zц.

Розрахунок координат промаху в картинній площі проводиться шляхом перетворення координат точки падіння БпЛА послідовним поворотом системи координат на кут $\Psi_{\text {та }} \Theta_{\mathrm{i}}$ переносом початку координат у точку прицілювання за формулою:

$$
\left.\begin{array}{l}
y_{\kappa}=-\left(X_{3}-X_{u}\right) \cos \psi \sin \theta+\left(y_{3}-y_{u}\right) \cos \theta+\left(Z_{3}-Z_{u}\right) \sin \psi \cos \theta \\
Z_{\kappa}=\left(X_{3}-X_{y}\right) \sin \psi+\left(Z_{3}-Z_{u}\right) \cos \psi
\end{array}\right\}
$$


У випадку, якщо координати падіння БпЛА виміряні на площині, що має нахил відносно площини землі під кутом $\chi$ (наприклад бокова поверхня залізобетонного укриття) відносно точки прицілювання, яка лежить в цій площині, тоді розрахунок промаху можливо вести за формулою:

$$
\left.\begin{array}{l}
y_{\kappa}=-\left\{\frac{X_{3}}{\sin \theta^{*}}\left[\cos \psi \sin \left(\chi-\theta^{*}\right)+\sin \psi \cos \theta^{*} \operatorname{tg} \psi\right]-Z_{3} \sin \psi\right\} \sin \theta \\
Z_{\kappa}=Z_{3} \cos \psi-X_{3} \cos \chi \sin \psi
\end{array}\right\}
$$

За допомогою цієї формули визначаються координати промаху БпЛА в квадратній площині відносно точки прицілювання.

Координати падіння БпЛА визначаються безпосередньо визначенням координат на грунті.

Основним засобом визначення кутів підходу $\theta^{*}$ та $\psi \in$ зовнішньо траєкторні вимірювальні засоби. Використовуються середні дані за 2-3 секунди до падіння.

Визначення оцінки математичного очікування координат центру групування точок влучання в картинній площі:

$$
\begin{gathered}
\tilde{m}_{y_{\kappa}}=\frac{\sum_{i=1}^{n} y_{i}}{n} ; \\
\tilde{m}_{z_{\kappa}}=\frac{\sum_{i=1}^{n} z_{i}}{n},
\end{gathered}
$$

де n-число пусків; $\mathrm{y}_{\mathrm{i}}, \mathrm{z}_{\mathrm{i}}$ - координати точки влучання в картинній площині в кожному заліковому пуску.

Визначення оцінки середньої квадратичної помилки від центру групування по вісі:

$$
\tilde{\delta}_{y_{\kappa}}=\sqrt{\frac{\sum_{i=1}^{n}\left(y_{i_{\kappa}}-m_{y_{\kappa}}\right)^{2}}{n-1}}, \tilde{\delta}_{z_{\kappa}}=\sqrt{\frac{\sum_{i=1}^{n}\left(z_{i_{\kappa}}-m_{z_{\kappa}}\right)^{2}}{n-1}} .
$$

Враховуючи високу вартість проведення експерименту щодо визначення показників точності, доцільно для попередньої оцінки системи наведення БпЛА проводити його за методикою шляхом проходу БпЛА над мішенню (не менше 9 разів) [3].

Наведення на ціль здійснюється відповідно до експлуатаційної документації. У районі мішені (рис. 1) розташовується зовнішній пілот (оператор) 3 дистанційним пультом керування. При наближенні БпЛА, в автоматичному режимі, до мішені на відстань до 10 м, зовнішній пілот (оператор) бере керування БпЛА на себе та здійснює маневр 3 метою відведення БпЛА від цілі (рис.2) . 


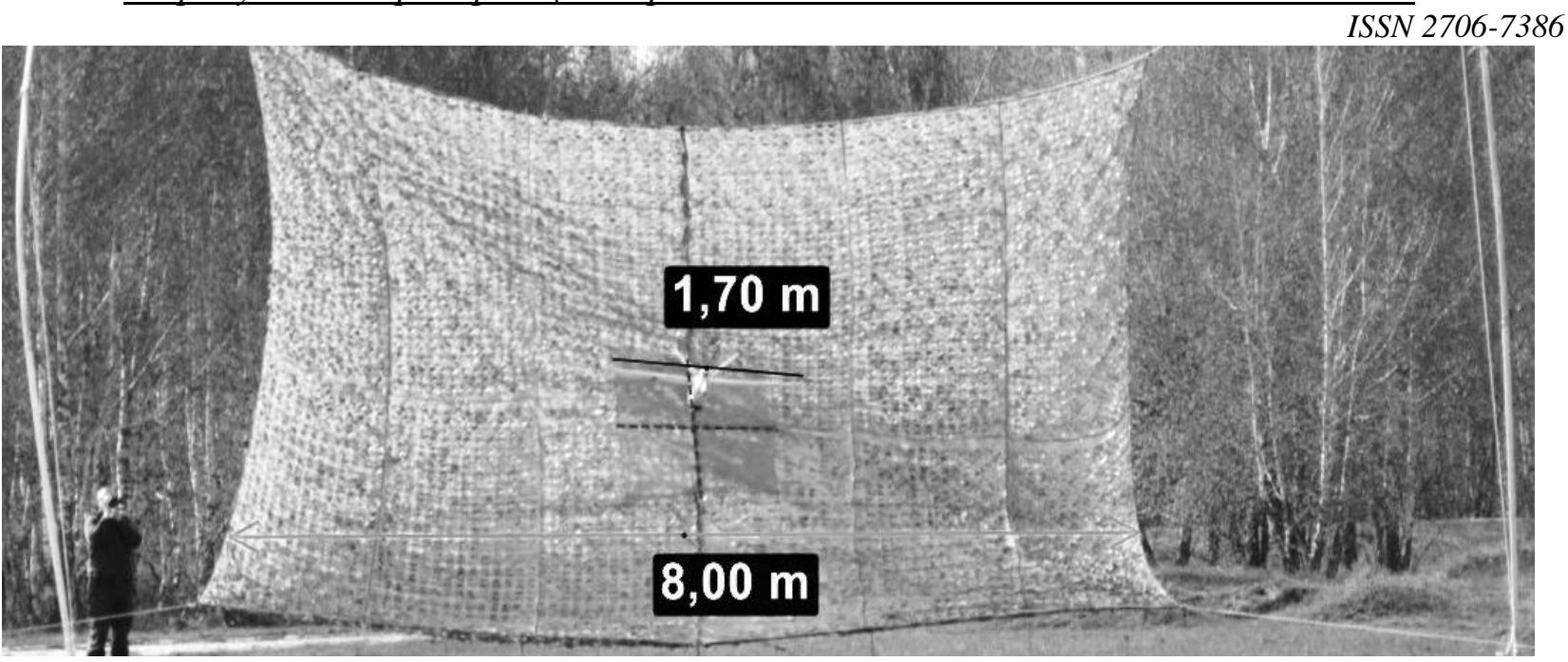

Рис.1. Мішень

За допомогою оптичних засобів (фото-відеокамер) та засобів траєкторних вимірювань здійснюється визначення відхилення вектору швидкості БпЛА $\overrightarrow{V_{\text {БплА }}}$ від центру мішені промах $D_{\text {пром. }}$ (по вісі $O X$ та $O Y$ )

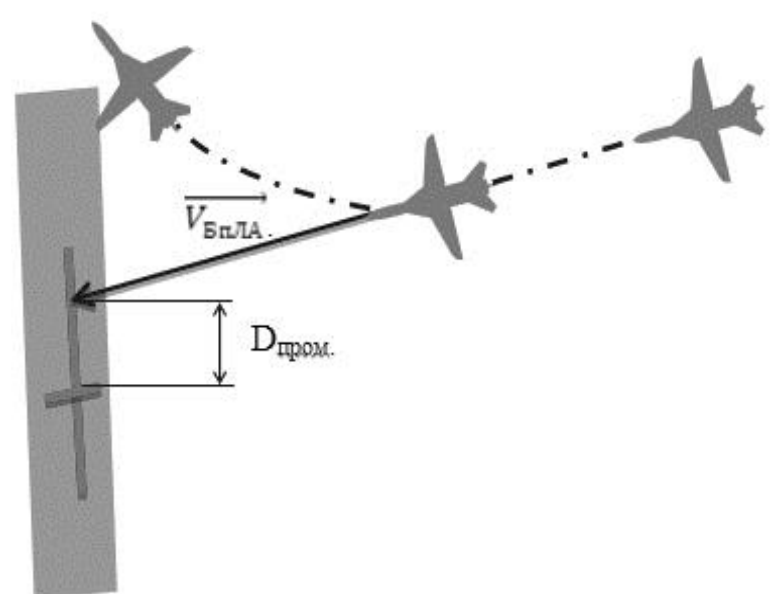

Рис.2.Схема наведення БпЛА при визначенні можливості виконання атаки на ціль

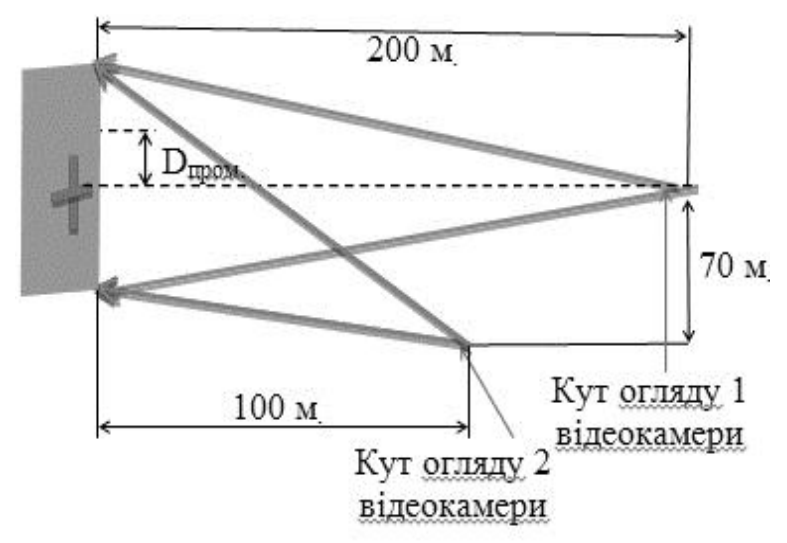

Рис.3.Схема розміщення відеокамер при визначенні можливості виконання атаки на ціль

За допомогою ПЗ Kinovea визначаються відхилення по вісі, наприклад (рис. 4)

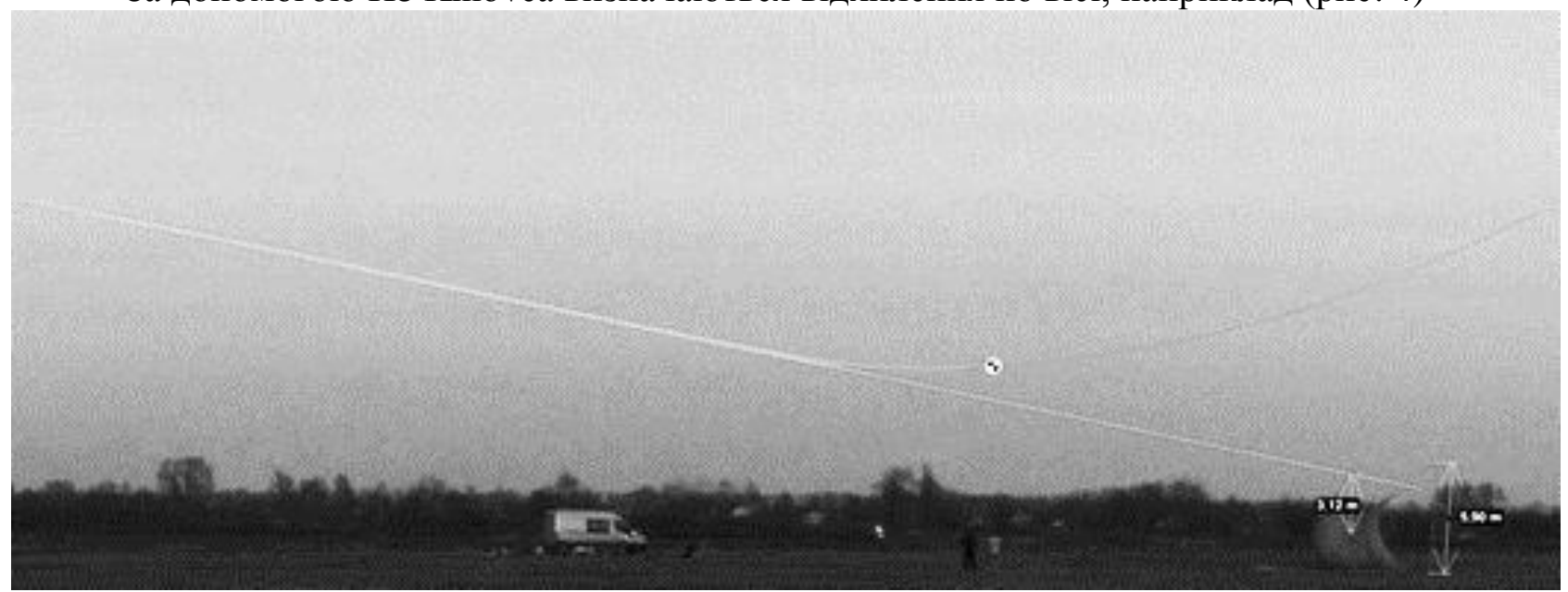

Рис.4.Відхиленя БпЛА по вісі $O У$

В ході експерименту отримано наведені в (Табл.2) результати. 
Відхилення при імітації атаки за допомогою оптичної системи наведення

\begin{tabular}{|c|c|c|c|}
\hline Номер заходу & $\begin{array}{c}\text { Відхилення } \\
\text { по вісі } O X_{3} \text { м }\end{array}$ & $\begin{array}{c}\text { Відхилення по } \\
\text { вісі } O Y_{3} \text { м }\end{array}$ & $\begin{array}{c}\text { Результат влучання по } \\
\text { кожному заходу }\end{array}$ \\
\hline 1 & \multicolumn{2}{|c|}{ Не заліковий (зрив захвату) } & Поза межами цілі \\
\hline 2 & 0,7 & 13,68 & Поза межами цілі \\
\hline 3 & 3,44 & 2,52 & В межах умовної цілі \\
\hline 4 & 0,5 & 5,06 & В межах умовної цілі \\
\hline 5 & Не заліковий (зрив захвату) & Поза межами цілі \\
\hline 6 & 0,37 & 6,10 & В межах умовної цілі \\
\hline 7 & 5,05 & 2,11 & В межах умовної цілі \\
\hline 8 & 3,10 & 2,72 & В межах умовної цілі \\
\hline 9 & 6,98 & 3,12 & В межах умовної цілі \\
\hline 10 & Не заліковий (зрив захвату) & Поза межами цілі \\
\hline 11 & 3,58 & 4,33 & В межах умовної цілі \\
\hline 12 & 10,29 & 3,29 & В межах умовної цілі \\
\hline $\begin{array}{c}\text { Математичне очікування } \\
\text { координат центру групування } \\
\text { точок влучання в картинній } \\
\text { площі }\end{array}$ & 3,77 & 4,77 & В межах умовної цілі \\
\hline
\end{tabular}

Математичне очікування координат центру групування точок влучання в картинній площі: $\tilde{m}_{x_{\kappa}}=\frac{\sum_{i=1}^{n} x_{i}}{n}=\frac{0,7+3,44+0,5+0,37+5,05+3,1+6,98+3,58+10,29}{9}=3,77(\mathrm{~m})$; $\tilde{m}_{y_{k}}=\frac{\sum_{i=1}^{n} y_{i}}{n}=(13,68+2,52+5,06+6,10+2,11+2,72+3,12+4,33+3,29) / 9=4,77(\mathrm{M})$.

Середньої квадратичної помилки від центру групування по вісі:

$$
\begin{gathered}
\tilde{\delta}_{y_{\kappa}}=\sqrt{\frac{\sum_{i=1}^{n}\left(y_{i_{\kappa}}-m_{y_{\kappa}}\right)^{2}}{n-1}} ; \\
\tilde{\delta}_{y_{\kappa}}=\left(\frac{(13,68-4,77)^{2}+(2,52-4,77)^{2}+(5,06-4,77)^{2}+(6,1-4,77)^{2}+(2,11-4,77)^{2}}{9-1}+\right. \\
\left.+\frac{(2,72-4,77)^{2}+(3,12-4,77)^{2}+(4,3-4,77)^{2}+(3,29-4,77)^{2}}{9-1}\right)^{\frac{1}{2}}=3,57(\mathrm{~m}) ; \\
\tilde{\delta}_{x_{\kappa}}=\sqrt{\frac{\sum_{i=1}^{n}\left(x_{\left.i_{\kappa}-m_{y_{\kappa}}\right)^{2}}^{n-1}\right.}{n-3,}} ; \\
\tilde{\delta}_{x_{\kappa}}=\left(\frac{(0,7-3,77)^{2}+(3,44-3,77)^{2}+(0,5-3,77)^{2}+(0,37-3,77)^{2}+(5,05-3,77)^{2}}{9-1}+\right. \\
\left.+\frac{(3,1-3,77)^{2}+(6,98-3,77)^{2}+(3,58-3,77)^{2}+(10,29-3,77)^{2}}{9-1}\right)^{\frac{1}{2}}=3,28(\mathrm{~s}) .
\end{gathered}
$$

Висновки. У ході проведення НДР фахівці ДНДІ ВС ОВТ здійснили апробацію методів та способів проведення випробувань БПАК типу “камікадзе" з термобаричною бойовою частиною, що дозволить, враховуючи отриманий досвід, підвищити в майбутньому якість проведення випробувань БпАК зазначеного типу за допомогою математичних методів, не втрачаючи коштовний літальний апарат. 
Збірник наукових пращь Державного науково-дослідного інституту випробувань і сертифікачї̈ озброєння та військової техніки. 2019. Вип. № 2

ISSN 2706-7386

Варто зауважити, що в цій статті освітлювалася лише частина показників та критеріїв, що підлягала оцінці під час випробувань, решта оцінювалась за аналогією з іншими БпАК та керованими системами озброєння.

\section{СПИСОК ЛІТЕРАТУРИ}

1. Собора А.І. Модель формування раціонального складу засобів вимірювань мобільного полігонного вимірювально-обчислювального комплексу / A.I. Собора // Збірник наукових праць Харківського національного університету Повітряних Сил. - 2017. - № 5(54). - C. 167-171.

2. Зозуля В. М. Розробка методики визначення швидкості руху та кута сходу авіаційних засобів ураження 3 використанням цифрових засобів відеореєстрації / В. М. Зозуля, О. В. Рижков, Ю. М. Добришкін, А. І. Собора // Наука і техніка Повітряних Сил Збройних Сил України. - 2016. - №2(23). - С. 96-98.

3. Пат. 117162 Україна, МПК G01C 11/26. Спосіб визначення швидкості руху та кута сходу авіаційних засобів ураження 3 використанням цифрових засобів відеореєстрації / Башинський В.Г., Зозуля В.М. та ін. ; заявник та патентоотримувач Державний наукововипробувальний центр ЗС України. -№ а201700410 заяв. 16.01.2017; опубл. 26.06.2017. Бюл. № 12.

\section{Солодчук Максим Олександрович}

старший науковий співробітник Державного науково-дослідного інституту випробувань і сертифікації озброєння та військової техніки, Чернігів, Україна https://orcid.org/0000-0002-1162-6784 +38093-556-54-77

\section{Телевний Ігор Володимирович}

заступник начальника Державного науково-дослідного інституту випробувань і сертифікації озброєння та військової техніки з випробувань, Чернігів, Україна https://orcid.org/0000-0003-0761-3013 e-mail: niv_dndi@ukr.net

\section{Геращенко Максим Михайлович} провідний науковий співробітник Державного науково-дослідного інституту випробувань і сертифікації озброєння та військової техніки, Чернігів, Україна https://orcid.org/0000-0001-6587-0355 +38095-535-61-72

\section{Сподін Олександр Іванович}

Провідний конструктор ТОВ

“Адрон”, Київ, Україна

https://orcid.org/0000-0002-9843-1145

+38067-789-34-98

\section{Maksym Solodchuk}

Senior Researcher of State Scientific Research Institute of Armament and Military Equipment Testing and Certification, Chernihiv, Ukraine https://orcid.org/0000-0002-1162-6784 +38093-556-54-77

\section{Televnyi Igor}

Deputy Chief of State Scientific Research Institute of Armament and Military Equipment Testing and Certification (on Research), Chernihiv, Ukraine https://orcid.org/0000-0003-0761-3013 e-mail: niv_dndi@ukr.net

\section{Maksym Gerashchenko}

Lead Researcher of State Scientific Research Institute of Armament and Military Equipment Testing and Certification, Chernihiv, Ukraine https://orcid.org/0000-0001-6587-0355 $+38095-535-61-72$

\section{Alexander Spodin}

НВФ Lead Designer of Adron and Development Co.Ltd, Kyiv, Ukraine https://orcid.org/0000-0002-9843-1145 +38067-789-34-98 


\author{
Брайко Володимир Вікторович \\ Провідний конструктор ТОВ \\ “Адрон”, Київ, Україна \\ https://orcid.org/0000-0002-8273-8919 \\ $+38067-402-07-39$
}

\section{Vladimir Braiko}

HBФ Lead Designer of Adron and Development Co.Ltd, Kyiv, Ukraine https://orcid.org/0000-0002-8273-8919 $+38067-402-07-39$

\section{SPECIAL ASPECTS OF TESTING THE KAMIKAZE-TYPE UNMANNED AERIAL SYSTEM WITH THERMOBARIC WARHEAD}

\section{Solodchuk, I. Televnyi, M. Gerashchenko, A. Spodin, V. Braiko}

In the context of annexation of the Autonomous Republic of Crimea by the Russian Federation and its involvement in the armed aggression on the eastern part of Ukraine, the issue of re-equipping the Armed Forces of Ukraine with modern weapons systems became urgent.

Conducting combat operations under conditions where the enemy carries out acts of armed aggression covering themselves with civilians, the Armed Forces of Ukraine require high-precision weapons, which will allow the destruction of targets with high-probability and, at the same time, ensure the safety of civilians. From all the variety of armament and military equipment developed by the Ukrainian industry, it is necessary to distinguish the kamikaze-type attack Unmanned Aircraft Systems (UAS). At the same time, there are no systematic approaches for testing the Unmanned Aircraft Systems of this type and accordingly there are no programmatic and methodological documents for the evaluation of such systems.

Taking into account the lack of typical Kamikaze-type Unmanned Aircraft Systems testing programs and methods, it was decided to form a hierarchy of indicators and criteria that would allow Unmanned Aircraft Systems to be evaluated as sample of armament and military equipment based on NATO experience.

A set of recommendations is proposed to improve the quality of the organization and performance of testing the Kamikadze-type UAS with thermobaric warhead.

During the Research work "Investigation of the possibility of using Unmanned Aircraft Systems manufactured by TOV "KORT" (Limited liabilities company) in the interests of the Armed Forces of Ukraine", the specialists of the State scientific research institute of armamemnt and military equipment testing and certification tested the methods and techniques of conducting tests of kamikaze- type Unmanned Aircraft Systems with thermobaric warhead, which will allow, considering gained experience, to improve in the future the quality of Unmanned Aircraft Systems tests of the specified type using mathematical methods without loss of valuable aircrafts.

It is worth noting that this article covered only a portion of the indicators and criteria to be evaluated during the tests, the rest was evaluated using analogy with other Unmanned Aircraft Systems and Managed Weapon Systems.

Keywords: unmanned combat aerial vehicle, programs and techniques for conducting UAV tests, UAS with thermobaric warhead, UAS tests. 